

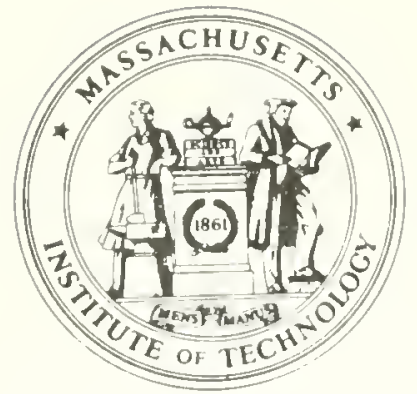

LIBRARY

OF THE

MASSACHUSETTS INSTITUTE

OF TECHNOLOGY 

Research Program on the ORGANIZATION AND MANAGEMENT OF R AND D Semi-annual Progress Report June 30,1964 


$$
\begin{aligned}
& 1520 \\
& 4414 \\
& \therefore 78-64
\end{aligned}
$$


Research Program on the

ORGANIZATION AND MANAGEMENT OF R AND D

In the spring of 1962 the MIT School of Industrial Management, with the encouragement and financial support of the National Aeronautics and Space Administration, undertook to develop a program of research and education on the problems of organizing and managing large-scale technology-based enterprises. The studies now in progress and planned for the future are focused on the broad objective of understanding and improving the effectiveness of $R \& D$ activities. Statements of the underlying concepts which guide the program appear in talks delivered at the 17 th Annual Conference on the Administration of Research, September 1963 (Marquis, 1964), * and at the September 1963 international convention of The Institute of Management Sciences (Roberts, 1963).

The principal researchers are faculty members whose backgrounds are in a variety of disciplines: mathematics, sociology, operations research, psychology, statistics, economics and engineering. Research assistants are selected from graduate student candidates for the S.M. or Ph.D. degree. A list of personnel active during the period of this report is presented in Appendix 1.

The program is administered by a research director and an associate director, guided by a steering Committee of seven faculty members (Appendix 1). Coordination is achieved by a weekly research seminar, by many small ad hoc groups, and by numerous informal consultations. The"Friday Seminar" is regularly attended by the faculty and student staff and by a number of guests from other MIT schools and Harvard, from industry, and from NASA. The seminars serve as a forum for reports of progress and plans, with discussion and debate on 
NOY @ 1965

N.... 1. LISRARIES 
questions of research design, methods, and interpretation. Outside guests are frequently invited to present papers growing out of operating experiences or relevant research. A list of topics and speakers is presented in Appendix 2.

\section{EDUCATIONAL ACTIVITIES}

A series of 14 weekly lecture-discussions on the organization and management of $R$ and $D$, each led by a different faculty member, is regularly offered each spring semester. The series is open to graduate students, Sloan Fellows, and guests from other departments and universities and from local industrial and government laboratories. The topics and session leaders for the 1964 series is presented in Appendix 4.

A one-day seminar for 200 industrial research executives was presented in the Kresge Theater March 5, 1964 under the auspices of the MIT Industrial Liaison Office. Current research findings were described by Professors Evan, Marquis, Muller-Thym, Roberts, and Stedry。

Sessions on research management have been introduced into the curriculum of the Program for Senior Executives and the Sloan Executive Development Program, and the advanced Industrial Dynamics course offered during the spring featured use and analysis of an $R$ and $D$ management game designed by Professor Roberts.

\section{RESEARCH PROJECTS}

In the following pages each of the research projects is described in terms of its current status, the nature of present results, and plans for the immediate future. 
Continuing the application of the philosophy and methods of Industrial Dynamics to the problems of $R$ and $D$ management, the investigator has been developing dynamic system models of three different problem areas. The first model of a general dynamic theory of project management is described in a book published in June (Roberts, 1964). The associated system modeling effort is now completed.

The second study is aimed at development of a general model of a technology-based enterprise, one in which the creation and use of technical knowhow is essential to organization effectiveness. The model includes consideration of management policy for allocation of engineering and management resources, technical recruiting and marketing, internal stress on product quality and schedule performance, etc. The initial model developed in this research has been modified for use as a Research and Development Organization Management Game, and tested in the advanced Industrial Dynamics course. Further development of the model and game will continue during the coming year.

The third systems model to be constructed will include government and industry aspects of the government $R$ and $D$ contracting system. This model, part of the investigator's research program on the contracting system, is now in its formulative phase.

In association with this project two Sloan Fellows completed theses which further advance the state-of-the-art of system models of technologybased enterprises. Fryling (1964) examined the management problems of introducing technical products into competitive markets. Kanter (1964) investigated management of commercial $R$ \& $D$ with emphasis on engineer allocation between product improvements and new product developments.

Research on this project is supported in part by a grant from the National Aeronatics and Space Administration. 


\section{Laboratory Management and Effectiveness R. B. Maffei \\ D. G. Marquis}

This project is obtaining systematic information from a number of research organizations for comparative statistical study. Data have been collected from 20 laboratories which are performing contract $\mathrm{R}$ and $\mathrm{D}$ for the government. In the immediate future, the emphasis will be placed on industrial laboratories which are primarily engaged in commercial $\mathrm{R}$ and $\mathrm{D}$ but also perform governmentfunded $R$ and $D$.

A question of major concern is whether government funds for $R$ and $D$ in industry stimulate privately-financed $R$ and $D$ expenditure or are merely a substitute for it. Blank and Stigler, using 1952 aggregate industry data, concluded that there was a considerable but uncertain amount of substitution. Re-examination of the earlier data and analyses of more recent data indicate that when the data are structured by industry they reveal a relationship which differs according to industry. There is an apparent positive relationship in those industries where $R$ and $D$ is supplementary to normal commercial activity, but a substitution effect in those industries heavily committed to $R$ and D (Black, 1964).

The investigation will, for the near future, concentrate on the following special points: the interaction of private-funded and public-funded $R$ and D within single industrial laboratories; differences in policy, planning, and control that seem appropriate to the different types of laboratories; the effect of these differences on laboratory performance; and the influence of the competitive environment in which the firm operates. Inquiries will be focused on firms in a selected small industry which has a well defined common technology. The study will be extended by adding additional such industries.

After July 1, 1964 the research will be directed by Dr. Guy Black, replacing Dr. Maffei who has resigned. The project is supported by a grant from the National Aeronautics and Space Administration. 
R. B. Maffei

D. G. Marquis

A.J.. Hansen

J.E. Mahoney

I.M. Rubin

Methods of obtaining comparable data on a large number of projects have been devised in order to carry out statistical analyses of the effect of important variables on performance of $R \& D$.

A preliminary formulation of critical variables was first prepared on the basis of published literature and interviews with experienced research managers. Field work has been concentrated on projects in industrial laboratories which are (1) conducted under contract with a government agency (or a prime), (2) between $\$ 1$ million and $\$ 25$ million in size, and (3) completed or nearly completed. Data have been collected on about 20 projects, and during the summer of 1964 the number will be increased to 50 .

Project performance is measured in several ways: (1) objective records of cost, time, and technical accomplishment are compared with the estimates and requirements in the contract; (2) judgments of performance are obtained from the project manager, the laboratory director, and the government technical representatives; (3) an account of the critical problems, slippages, and failures in the course of the project, together with the steps taken in response, are obtained from the project manager and the technical monitors.

Information on a number of features of the organization and management of each project is obtained from laboratory records, from government contracting offices, and from interviews with project managers, and will be analyzed in relation to project performance.

This project is supported by a grant from the National Aeronautics and Space Administration. 



\section{Government-Industry Contracting System}

E.B. Roberts

L. B. Berger

L.G. Pringle

J.B. Sloat

The goal of this project is the design of policies for a more effective government contracting system. The current research is divided into three phases: (1) determination of the decision process used for government award of research and development contracts; (2) study of company strategy and decision-making aimed at obtaining government contracts, including the role of company beliefs regarding the government award process; (3) development of a dynamic system model for computer simulation analysis of the contracting system, using the results of the phase one and two empirical studies as inputs.

Work on the first phase of the research program has included interviews and record analysis at three large government centers, one in NASA and two in DOD field centers. Project records have been studied in more than 100 competitive cost-plus $R$ and $D$ contracts which range in size from $\$ 100$ thousand to $\$ 40$ million. An additional sample has been developed for a study of sole-source $R$ and $D$ awards. Data extracted from agency records and interviews with source evaluation board members, project managers, negotiating officers, and others is producing a view of the actual system underlying contract awards, which differs markedly from the formal contracting system (Roberts, 1964 (b)).

The second phase of the research program involves an intensive interview program in cooperating companies to study corporate proposal strategy and $\mathrm{R}$ and D marketing activities. Preliminary findings are reported in two theses by Berger (1963), and Sloat (1964). In addition the companies that were the principal competitors for several contracts analyzed in phase one of this project will be contacted and key personnel interviewed to determine company views on government award decisions. A mail questionnaire will be used to gather additional information on company proposal decisions.

This project is supported by a grant from the National Aeronautics and Space Administration. 



\section{Space and Work in $R \& D \quad$ B. J. Muller-Thym \\ R. W. Puffer}

This project deals with the relationship between work and the space in which it is done. The research is focused on: (1) the identification of features of a project's spatial environment and how people feel about them; (2) the relationship of the dispersion of project personnel and their physical travel paths to the project's work-structure; (3) the relation of both (1) and (2) to the project's success or failure; and (4) the development of a system for classifying competences, and a language for describing their interaction, which may be used to construct general models of project structure.

Information on these subjects has been derived from an analysis of interview material gathered at the Goddard Space Flight Center. The analysis indicates that project personnel are far less concerned with environmental conditions such as noise or crowding than with the impact of physical constrictions on the flow of work and communication. It further demonstrates that problems such as crowding, as perceived by project personnel, bear little relationship to the actual measured conditions. For one project crowding actually led to a beneficial flow of information and a highly integrated work structure.

In addition, the evidence indicates that campus plan research centers may be detrimental to the performance of project-organized $R$ \& $D$ work. It suggests that one or more buildings of such a campus plan be completely reserved for project work in order to more effectively match space structure with project work structure.

Current results are presented in a thesis by Puffer (1964), and a more complete report is in preparation. The project is supported by a grant from the National Aeronautics and Space Administration. 


\section{Technical Quality of Competitive Proposals}

T. J. Allen

D. G. Marquis

M. P. Andrien

J. R. Brown

Research has demonstrated that the proposal competition provides an excellent opportunity for the study of factors influencing success in problemsolving. It is one of the rare real-life situations (along with multiple award contracts) in which a number of different firms work on the same task and can therefore be directly compared. Technical evaluations are obtained from the responsible government agency, and questionnaires completed by each firm provide information on the relevant characteristics of the firm and of the proposal effort.

Twenty-two USAF and NASA competitions were selected and approximately 200 questionnaires were mailed to the competing firms. Returns have been received from about 90 per cent. Analysis of these returns shows substantial agreement with results reported earlier (Allen and Marquis, 1964). Technical competence, as evidenced by use of company specialists and by size of technical work force, far outweighs other factors such as company size, proposal team size and technical man-hours of effort in influencing the technical quality of proposals; there is a strong indication that attempts to substitute for in-house competence by use of outside consultants are unsuccessful. The time spent examining literature is not correlated with the quality of the proposal.

A U-shaped relationship is found between the level of effort expended on the proposal and its technical rank. Firms in the upper half of the rankings show a direct relation between man-hours expended and technical ranking; firms in the lower half show an inverse relation. Apparently there exists a "threshold of competence", only above which does it pay to increase one's expenditure of effort.

This project was initiated with the support of a grant from the National Aeronautics and Space Administration and currently receives support from the National Science Foundation (Office of Science Information Services). 


\section{Problem Solving in Parallel $R \& D$ Projects}

T. J. Allen

M.P. Andrien

R.J. Bjelland

W. D. Putt

Parallel contracts afford the researcher an opportunity to make direct comparisons of the way different $R \& D$ groups perform the same tasks. In this project comparisons are sought between the technical approaches considered, the strategies employed, and the information sources utilized by the competing research groups.

Major NASA centers were visited and thirteen instances of multiple award contracts were selected. The contractors were visited to obtain their cooperation. Seventeen major companies are presently cooperating with the project. Project managers and lead engineers in each organization report their progress toward solution on specially designed Solution Development Records. Engineers working on the task maintain a record of their time spent in various information gathering activities and keep a log of literature sources employed. Each project manager is called by telephone once a month and asked to provide orally a resume of activities and technical decisions made during that month.

Preliminary results indicate a very high incidence (much higher than anticipated by the project managers) of complete reversals and re-reversals in decisions on technical approach. There is some indication that these changes are periodic, that the frequency of change in the parallel firms is correlated, and that the changes are a result of interaction among subsystem designs. In a final interview each major change is being linked to the relevant information sources.

This project was initiated with the support of a grant from the National Aeronautics and Space Administration and currently receives support from the National Science Foundation. 


\section{Information Systems for Planning and Control J. C. Emery \\ C. Ying}

The project is examining the role of the information system for planning and control in a large hierarchical organization having multi-dimensional goals. The initial phase of the study was devoted to the development of a conceptual model of the planning and control process which provides a means for assessing the technological requirements of the information system and its relation to the human decision maker.

The next phase of the research program will be devoted to the implementation of prototype components of the information system. The most important objective is the development of an information system that allows the manager to retrieve primitive data from the organization's data base. The retrieval request is expressed in a language permitting the flexible specification of logical search criteria. The language must further allow the specification of operations on the data in order to transform them into information useful for planning and control. A subsidiary project will examine the usefulness of such a man-machine system in a highly complex, interacting and stochastic environment.

This project was initiated with support of a grant from the National Aeronautics and Space Administration and is currently supported by the Sloan School of Management. 


\section{Career Development in Research Organizations}

E.H. Schein

W.W. McKelvey

The purpose of this project is to develop information concerning the career patterns of engineers, scientists, and administrators in NASA which would enable an individual to view more realistically his career development possibilities within the organization, thus contributing to greater effectiveness, creativity, and growth. A broader objective is to facilitate the design of organizational policies and procedures to increase the competence and contribution of researchers throughout their entire careers.

The first phase of the project was an exploratory one, undertaken in the summer of 1962, involving open-ended interviews, up to $2 \frac{2}{2}$ hours in length, with 96 men at the Langley and Lewis research centers. Results are reported in two papers (Peters, 1963; Schein, et al, 1964)。

The second phase of the project includes the development of a questionnaire which will reliably and validly measure the career orientation variables that have now been isolated. Finally, a more extensive questionnaire survey will be undertaken to provide data for a systematic analysis of the relationship between career orientations, perceptions of rewarded activity, and objective and demographic variables. It is expected that this phase will be substantially complete by October 1964 .

The project is supported by a grant from the National Aeronautics and Space Administration. 
A common structural feature of $R \& D$ laboratories, particularly those engaged in applied research and development, is the organization of personnel according to projects or tasks rather than, or in addition to, departments or disciplines. To achieve the objectives of a project, members of more than one discipline must interrelate and coordinate their activities.

In the performance of project research at least four types of conflict may arise: (a) task conflict among peers--disagreement among project members as to how to achieve the objectives of the project; (b) task conflict between one or more project members and the project director; (c) interpersonal conflict among peers--personal dislikes or mutual distrust among project members; (d) interpersonal conflict between one or more project members and the project director.

A questionnaire designed to measure personal, motivational and organizational factors affecting conflict and performance was pretested and administered to project groups in two industrial laboratories and two NASA centers. Preliminary findings, based on a relatively small number of cases, indicate that none of the four types of conflict seems to have a direct effect on the performance of project teams, but rather that the effect of conflict on performance is contingent upon several intervening or conditioning variables. For example, in project groups engaged in basic research technical conflict is associated with a higher level of performance, whereas in project groups engaged in applied research, conflict of any kind tends to lower performance. Similarly, the correlation between conflict and performance appears to be positive in teams whose members have a high tolerance for complexity, whereas it is negative in the others. Additional data are being collected in other $R$ \& $D$ organizations. This project is supported by a grant from the National Aeronautics and Space Administration. 
Study of unprogramed problem-solving behavior under carefully controlled laboratory conditions is one approach to understanding the creative research process. Previous experimental studies have made use only of short, relatively simple, and usually single-solution problems which do not approximate the complex processes involved in research and development work.

A problem-solving environment has therefore been designed which is: (a) sufficiently complex and flexible to provide opportunity for long-term systematic investigations of human thinking processes; (b) sufficiently well specified to permit application of rigorous experimental controls; and (c) sufficiently quantifiable to allow explicit measurement of behavior as well as direct comparison of alternative strategles of problem-solving. Parametric forms of such an experimental environment are programmed and have been run on both real-time and time-sharing computer systems.

Data have been obtained on the problem-solving performance of 18 men, each working over time periods extending to eight weeks, on a series of four problems in which prior knowledge would be either facilitating, interfering, or neutral for the solution process. Verbal protocols have been analyzed to determine the different types of strategies employed, and to construct flow charts of the observed processes. A tentative revision of the theory of problem solving has been formulated to account for the observed diversity of decision behavior, and to serve as an organizing framework for the next stage of research (Soelberg, 1964).

This project was initially supported by a grant from the National Aeronautics and Space Administration and currently recelves support from M.I.T. Project MAC. 



\section{Risk and Uncertainty in Research Decisions}

D. G. Marquis

J. Burns

J. Miller

In the process of research and development there is a succession of decisions involving various degrees of uncertainty. To supplement the several field studies of decision making, a series of experimental researches is being conducted to clarify particular questions.

Uncertainty, defined as incomplete information on the probabilities or values of the outcomes of a set of alternatives, has been found to have certain regular effects on decision choices and on strategies for reaching decisions. For example, individuals are found to choose less risky alternatives in the face of uncertainty than in comparable risk problems with greater certainty.

When five or six individuals who have already indicated their own decision choices are formed into a group which is instructed to discuss the problems and agree on a unanimous choice, the group decision is more risky than the average of the individuals' decisions. This effect is true only with problems involving uncertainty; there is no group effect with problems of pure risk choice.

Preliminary work indicates that there are clear differences among people. Anxious individuals (Alpert-Haber test) show a larger effect of uncertainty, and social conforming individuals (Marlowe-Crowne test) show a larger shift from individual to group decisions. Continuing experimental work is directed to the study of decision choices among sure wins (all alternatives have positive expected value) compared with choices among sure losses (negative expected value).

This project was initially supported by a grant from the National Aeronautics and Space Administration, and currently is supported by M.I.T. Project MAC and by a grant from the Los Altos Foundation. 


\section{Goal Structure and Organizational Behavior}

A.C. Stedry

M.M. Gold

R.H. Gawron

D. Abramovitch

The problems at the focus of this research are: (1) in what f(orm can (and should) organization goals be communicated to subordinate levels in the organization; (2) how do these communicated goals interact with goals of the subordinate organization and the individual aspirations of members of the subordinate organization; and (3) how do all of these goals taken together affect the total amount of effort managers will expend in goal attainment and the allocations of effort among the various areas of activity in which goals exist.

Theoretical work, assuming response to goals to be "quasi-rational," has investigated a function of reward based upon goal attainment to determine how a superior would allocate his effort to best attain his various budgets and how higher management could best utilize-the budget-setting mechanism to influence the effort allocation processes (Stedry and Charnes, 1963). Further investigation was undertaken to determine the optimal allocation of managerial effort in order to maximize the probability of attaining all goals--i.e., the contract specification problem (Charnes and Stedry, 1964).

Experimental work has attempted to show the effects of goals on individuals under various conditions in the laboratory. Gawron (1964) reports the effect of participation in goals setting and commitment to goals on performance. Gold (1964) found that instructions to play a role (e.g., sales manager) affected the subjects' willingness to call in an "outside consultant" to help attain his goals. Gold, Levy and Stedry (1964) found that setting goals (quotas) produced decision rules and effort allocations different from a piecework-type reward situation. Summaries of work on goal structures applied to the practical problems of budgetary control are reported by stedry (1964 a,b).

This project is supported by a grant to M.I.T. from the National Aeronautics and Space Administration. The theoretical work is also supported in part by a grant to Northwestern University (Charnes) from the Office of Naval Research. 
14. New Approaches to Project Management

E. B. Roberts

J.B. Sloat

A.L. Wood

During the past year a new study has been initiated with the purpose of investigating and developing improved approaches to the management of $R \& D$ projects. The investigator intends over the next several years to explore aspects of effort and cost estimation, program budgeting, and performance measurement and evaluation. These form a closed feedback-1oop of project control which is central to the $R \& D$ process.

Two studies under this general program are underway at present. The first is examining the impact of incentive contracting on project control and the results of a series of NASA CPFF contracts which have been converted to an incentive basis. Government and contractor personnel and records are providing the data for this inquiry, the initial results of which are reported in a thesis by sloat (1964).

The second study undertakes to develop an overview of the NASA budgeting process and at the same time to improve cost estimating and program planning methods. The over-all Apollo Program and its sub-components, such as Mercury, Gemini, and Saturn I, are being used as case studies for the research being carried out largely by A. L. Wood.

This project is supported by a grant from the National Aeronautics and Space Administration. 
This study has attempted to analyze the impact of $R$ \& $D$ by examining the functioning of the economy in the areas of economic growth, productivity increases, changes in the composition of the labor force, and changes in the quality and the role of education (with emphasis on science and engineering).

The findings thus far indicate that the economy has been functioning more efficiently in the postwar period than between 1909-1929, the first "normal" period before R \& D became a significant activity and for which there are good data. The measures of efficiency utilized were economic growth, stability, and increases in productivity. Long run trends in changes in the composition of the labor force appear to have accelerated and these trends have been linked to sectoral productivity increases and the changed role of education. Results are reported in two papers (Gruber, 1963; 1964).

Substantial progress has been made in the study of manpower requirements, and a monograph is nearly complete on productivity, education, and changes in the labor force in the postwar United States. The findings indicate that the sectors of the economy with the faster increases in productivity have experienced slower increases in employment. The net result of sectoral and occupational changes has been a more rapid transformation in manpower requirements in the postwar period than the long-run shifts that have occurred since 1900 .

A review of the findings to date indicates that $R$ and $D$ has been $a$ powerful force for economic change. The understanding of the changes fostered by $R$ and $D$ will be used in next steps to consider the future role of $R \& D$ and the ways in which its usefulness in the economy can be maximized while minimizing the disruptions which it causes.

This project is supported by the Sloan School of Management and by the M.I.T. Center for space Science. 


\section{STEERING COMMITTEE}

Jay W. Forrester, Professor of Industrial Management Howard W. Johnson, Dean, Sloan School of Management Donald G. Marquis, Professor of Industrial Management, Chairman James McCormack, Vice President, Massachusetts Institute of Technology Max Millikan, Professor of Economics and Director, Center for International Studies

Bernard J. Muller-Thym, Visiting Professor of Industrial Management Edward B. Roberts, Assistant Professor of Industrial Management John M. Wynne, Associate Dean, Sloan School of Management (absent on leave 1963-1964)

\section{ADMINISTRATIVE STAFF}

Donald G. Marquis, Research director

Edward B. Roberts, Associate research director

Joanne Fay, Secretary

Betty Benedetto, Clerk-typist

Hannelore Machotka, Clerk-typist

\section{FACULTY RESEARCH STAFF}

Thomas J. Allen, Jr.

Research Associate, Sloan School of Management

David Berlew

Assistant Professor of Industrial Management

Guy Black

Research Associate, Sloan School of Management

Irena Dubska

Research Associate, Sloan School of Management

James C. Emery

Assistant Professor of Industrial Management

William M. Evan

Associate Professor of Sociology and Industrial Management

Richard B. Maffei

Lecturer, Sloan School of Management

Dona ld G. Marquis

Professor of Industrial Management

Bernard J. Muller-Thym

Visiting Professor of Industrial Management

Edward B. Roberts

Assistant Professor of Industrial Management

Edgar H. Scheín

Associate Professor of Industrial Management

Peer Soelberg

Assistant Professor of Industrial Management

Andrew C. Stedry

Assistant Professor of Industrial Management

Charles Ying

Research Associate, Sloan School of Management 


\section{STUDENT RESEARCH ASSISTANTS}

Dan Abramovitch

S.B. Electrical Engineering, McGi11, 1961

Maurice P. Andrien

S.B. Electrical Engineering, MIT, 1963

Laurence B. Berger

S.B. Industrial Management, MIT, 1963

Richard J. Bjelland

B.A. General Science, Oregon State University, 1962

Robert Blain

B.A. Sociology, University of Massachusetts, 1960; M.A. Sociology,

University of Wisconsin, 1962

J. Randa 11 Brown

S.B. Electrical Engineering, MIT, 1963

James F. Burns

S.B. Math, University of Michigan, 1961; S.M. Economics, Columbia, 1963 James M. Gross

S.B. Industrial Management, MIT, 1961; S.M. Industrial Management, MIT, 1964.

Douglas T. Hall

S.B. Industrial Administration, Yale, 1962; S.M. Industrial Management, MIT, 1964

Adolph Hansen

S.B. Chemical Engineering, MIT, 1956; S.M. Industrial Management, MIT, 1964

James E. Mahoney

S.B. General Business, Florida State University, 1958; M.S. Industrial

Management, Florida State University, 1961

William McKelvey

A.B. Physics and Economics, Monmouth College, 1960

James R. Miller

A.B. Princeton University, 1959; M.B.A. Harvard Business School, 1963 John E. Osborne

A.B. Bethany College, Economics, 1963

Robert W. Puffer III

B.S. Electrical Engineering, MIT, 1962; S.M. Industrial Management, MIT, 1964

Lewis G. Pringle

B.S. Chemistry, Harvard University, 1963

William D. Putt

S.B. Industrial Management, MIT, 1959; S.M. Industrial Management, MIT, 1964

Irwin Rubin

S.B. Electrical Engineering, Tufts University, 1961; S.M. Industrial Management, MIr, 1964 Herbert L. Selesnick

S.B., Physics, MIT, 1962

J. Barry sloat

S.B. Engineering, UCLA, 1961, S.M. Industrial Management, MIT, 1964 John Thomas

S.B. Industrial Administration, Yale University, 1960 
January 10, 1964 W.R. Purcel1, et a 1., Harvard University Graduate School of Business Administration.

Project Report on Commercial Applications of Defense and Space Technology:

January 17, 1964 Richard S. Morse, Chairman of the Board, Cryogenics Corporation; Lecturer, M.I.T., Sloan School of Management. Problems of Conversion from Defense and Space $R \& D$.

February 14, 1964 General James McCormack, Vice President, M.I.T. The Role of the Special Non-Profit Corporation.

February 21, 1964 Robert W. Miller, Corporate Director of Management Science, Raytheon Company.

Pros and Cons of Multiple Incentive Contracting.

February 28, 1964 Discussion session on the nature of possible management research that could be carried out with the NASA Electronics Research Center.

March 6, 1964

General Arthur G. Trudeau, President, Gulf Research and Development Co., Former Chief of R \& D, U.S. Army. Remarks on the Management of Research and Development.

March 13, 1964 Peer Soelberg, Assistant Professor of Industrial Management, M.I.T., Sloan School of Management.

Toward a General Theory of Problem-Solving.

March 20, 1964 Charles F. Langenhagen, Partner, Allaco Products and Alexander and Langenhagen.

Anecdotes in the Growth of a Small Technology Based Company.

March 27, 1964 Andrew G. Swanson, M.I.T. Sloan Fellow, NASA.

Selection of Project. Managers--A.Study of the Decision Process in a Government Laboratory.

Steve Cenko, M.I.T. Sloan Fellow, General Motors. Obsolescence of Engineering Knowledge: A Management Problem.

April 10, 1964 Dr. Guy Black, Research Associate, M.I.T. Sloan School of Management.

Substitution of Public for Private $R \& D$ Expenditures.

April 17, 1964 Dr. D. A. Sutton, Director of Research, The Gelatin and Glue Research Association, England.

Research Associates in Great Britain.

April 24, 1964 Dr. Norman Waks, Special Assistant for Systems Acquisition and Economics, and Robert L. Hamilton, Head, Management Systems, The MITRE Co.

The Information Systems Acquisition Process Study. 

May 1, 1964

May 8, 1964

May 15,1964

May 22, 1964
Dr. Homer E. Newe11, Associate Administrator, Space Science and Applications, NASA

Some Aspects of the NASA Space Science Program

Frank G. Carr, Director, Headquarters Business Systems Research, Development and Application, Westinghouse Electric Corporation. Lecturer, M.I.T. Sloan School of Management

Introduction of Computers in a Large Corporation:

Organizational Response to Technological Innovation.

Andrew C. Stedry, Assistant Professor of Industrial

Management, M.I.T. Sloan School of Management

Resource Allocations Where All Product Specifications Must be Met.

Dr. Austin W. Fisher, Jr., Corporate Vice President for $R$ and $D$, Ludlow Corporation.

Factors Influencing the Rate of Diffusion at the $R \& D$ Interface. 
SLOAN SCHOOL OF MANAGEMENT THESES COMPLETED 1964

Graduate Students

Larry Berger, S.B., Industrial Administration, M.I.T., 1963

A study of company strategy toward research and development proposals Professor Roberts

Rudolph H. Gawron, S.B., Industrial Management, M.I.T., 1963

The effects of participation and commitment on organizational performance Professors Evan and Stedry

Robert E. Good, B.A., Business Administration, Antioch College, 1962

Creativity and individual differences in problem solving

Professors Marquis and Soelberg

Marvin Hersh, S.B., Chemical Engineering, M.I.T., 1961

Investigation into PERT, a new management technique for $R$ \& $D$ programs Professors Maffei and Smith

J. Steven Ott, S.B., Labor Management Relations, M.I.T., 1960

A questionnaire study of organizational climate

Professors McGregor and Schein

Robert W. Puffer, S.M., Industrial Management, M.I.T., 1964

Work, space, and communication: a study of research and development

Professors Muller-Thym and Roberts

William Putt, S.B., Industrial Management, M.I.T., 1959

Managerial reactions to reductions in resources in research and development Professors Marquis and Stedry

Graciano Sa, S.B., Electrical Engineering, U. Rio Grande De Sul, 1958

A study of the solutions to PERT networks

Professors Little and Pounds

J. Barry Sloat, S.B., Engineering, UCLA, 1961

Incentive contracting for research and development procurements: a case study

Professor Roberts, T.J.Allen

Sloan Fellows in Executive Development

Nicholas Baracos, Manager, Suspension and Steering Department, Ford Division Product Engineering Office, Ford Motor Company

The dynamic behavior of an automotive engineering organization

Professors Muller-Thym and Roberts

Steve Cenko, Chairman, Mechanical Engineering Laboratories Department,

General Motors Institute

Factors in obsolescence of engineering knowledge

Professors Schein and Smith 
George P. Fryling, II, Vice President--Operations, Erie Technological Products Corp. The dynamic problems of introducing a competitive product to the market Professors Pounds and Roberts

Lawrence Kanter, Program Manager, Data Systems Division, Product Development Laboratory, International Business Machines Corporation

An investigation of the interaction between the depth and breadth of $R \& D$ endeavor and the growth of the company

Professors Roberts and Smith

T. Frank Morring, Technical Staff Assistant, George C. Marshall Space Flight

Center, National Aeronautics and Space Administration

The impact of space age spending on the economy of Huntsville, Alabama Professors Evan and Siegel

David H. Oswalt, Assistant for General Research Agreements, Pricing Division, Air Force Systems Command, United States Air Force

Analysis of Department of Defense policies toward independent research and development

Professors Marquis and Muller-Thym

Robert E. Pace, Jr., Assistant Agena System Manager, George C. Marshall

Space Flight Center, National Aeronautics and Space Administration

A atudy of the project manager's influence on technical. support groups

in a project overlay organization

Professors Marquis and Berlew

Philip A. Piro, Program Manager, Range Instrumentation Program, Radio Corporation of America

The military electronics industry and foreign markets

Professor Bowles and Maffei

Andrew G. Swanson, Assistant Head, Vehicle Performance Branch, Applied Materials and Physics Division, Langley Research Center, National Aeronautics and Space Administration

Selection of project managers in a government research laboratory:

a study of the decision process

Professors Marquis and Pounds 
ORGANIZATION AND MANAGEMENT OF RESEARCH AND DEVELOPMENT

A Series of Lecture Discussions

Course 15.384

Thursdays, 3:30-5 p.m., Room 52-161

Donald G. Marquis, Moderator

February 13, 1964 Introduction: Nature of $R$ and $D$

February 20, 1964 Thomas J.Allen, Research Associate, SIM

The $R$ and D Process: Problem Solving

February 27, 1964 Donald G. Marquis, Professor of Industrial Management Evaluation and Prediction of Individual Performance

March 5, 1964

Andrew C. Stedry, Assistant Professor of Industrial Management Motivation and Performance

March 12, 1964

William M. Evan, Associate Professor of Sociology Effectiveness of $R$ and D Groups

March 19, 1964

Edgar H. Schein, Associate Professor of Industrial Management Supervisory Management

March 26, 1964

William F. Pounds, Assistant Professor of Industrial Management Project Organization and Management

Apri1 9, 1964

Edward B. Roberts, Assistant Professor of Industrial Management Government-Industry Contracting Process

Apri1 16, 1964

Bernard J. Muller-Thym, Visiting Professor of Industrial Management Space, Communication, and Work

Apri1 23, 1964

James C. Emery, Assistant Professor of Industrial Management Management Information Systems

April 30, 1964

Martin H. Weingartner, Associate Professor of Finance Construction of the Corporate Research Program

May 7, 1964

Donald G. Marquis, Professor of Industrial Management Corporate Organization and Policy

May 14,1964

William H. Gruber, Lecturer in Industrial Management Impact of $\mathrm{K}$ and $\mathrm{D}$ on Economic Growth

May 21, 1964

Robert C. Wood, Professor of Political Science

National Policy and Organization 


\section{PUBLICATIONS}

Single copies of available publications will be supplied on request.

Allen, T.J. Jr., \& Marquis, D.G. Problem solving by research groups: factors influencing technical quality in the preparation of proposals for government contract. M.I.T., Sloan School of Management Working Paper No. 20-63, July 1963.

Allen, T.J. Jr., \& Marquis, D.G。 Positive and negative biasing sets: the effects of prior experience on research performance. M.I.T., Sloan School of Management Working Paper No. 21-63, July 1963.

Allen, T.J. Jr., \& Marquis, D.G. The R \& D proposal: study of factors influencing technical quality. M.I.T., Sloan School of Management Working Paper No. 68-64, 1964.

Allen, T.J.Jr., \& Putt, W.D。 A comparative study of technical information requirements in parallel research and development. M.I.T., Sloan School of Management Working Paper No. 69-64, 1964.

Black, G. Substitution of public for private research and development expenditures. M.I.T., Sloan School of Management Working Paper No. 57-64, Apri1, 1964.

Bok, E.C. Making American space policy: (1) the establishment of NASA. M.I.T., Sloan School of Management Working Paper No. 09-63, January 1963.

Cenko, S., \& Marquis, D.G. Factors in obsolescnce of engineering knowledge. M.I.T., Sloan School of Management Working Paper No. 77-64, 1964.

Charnes, A, \& Stedry, A.C. Investigations in the theory of multiple budgeted goals. In C. P. Bonini, R. K. Jaedicki and H. M. Wagner (eds) Management Controls: New Directions in Basic Research, New York: McGraw-Hi11, 1964.

Clarkson, G.P.E., \& Pounds W.F. Theory and methods in the exploration of human decision behavior. Industrial Management Review, 1963, 5, 17-27.

Evan, W.M. The engineering technician: dilemmas of a marginal occupation. M.I.T., sloan School of Management Working Paper No. 36-63, September 1963.

Gawron, R.H. The effect of participation and commitment on organizational performance. M.S. Thesis, M.I.T. 1964.

Gold, M.M., Levy, S.M., \& Stedry, A.C. The effect of goals on bidding response. M.I.T., Sloan School of Management Working Paper No. 74-64, 1964.

Greer, C.H. CPIF: The new look in R \& D Management. M.I.T., Sloan School of Management Working Paper No. 65-64, May 1964.

Gruber, W.H. What can we expect from our new economy? M.I.T., Sloan School of Management Working Paper No. 35-63, September 1963. 

Hansen, A.J. \& Marquis, D.G. Can creativity be predicted in research professionsals? M.I.T., Sloan School of Management Working Paper No. 73-64, 1964.

Marquis, D.G. Individual responsibility and group decisions involving risk. Industrial Management Review, $1962, \underline{3}, 8-23$.

Oswalt, D.H. Attitudes toward DOD policies on independent $R$ and D. M.I.T., Sloan School of Management Working Paper No. 72-64, 1964

Pace, R.E. \& Marquis, D.G. The project manager in a matrix overlay organization. M.I.T., Sloan School of Managenent Working Paper No. 71-64, 1964.

Peters, D.R. Notes on career growth in NASA: patterning of interview responses. M.I.T., Sloan School of Management Working Paper 17-63, 1963.

Roberts, E.B. The Dynamics of Research and Development. New York: Harper and Row, 1964 (a) (order from publisher).

Roberts. E.B. How the U.S. brys research. Intern. Science \& Techn., Septemter, $1954(3)$.

Roberts, E.B. The design of research and development policy. M.I.T., Sloan School of Management Working Paper No. 08-63, January 1963 (a).

Roberts, E.B. Industrial dynamics and the design of management control systems. Management Technology, 1963 (b), $\underline{3}$, No.2, 100-118.

Roberts, E.B. Engineer dynamics and productivity in R \& D projects. M.I.T., Sloan School of Management Working Paper No. 37-63, October 1963 (c).

Rubin, I., Stedry, A.C., \& Willits, R.D. Effort allocation by research and development managers. M.I.T., Sloan School of Management Working Paper No. 75-64, 1964 .

Schein, E.H., McKelvey, W., Peters, D., \& Thomas, J. Career orientations and perceptions of rewarded activity in a research organization. M.I.T., Sloan School of Management Working Paper No. 56-64, May 1964.

Soelberg, P.0. Possibilistic compromise, a model of decision making. M.I.T., Sloan School of Management Working Paper No. 50-64, March 1964.

Swanson, A.G. The decision process in project manager selection. M.I.T., Sloan School of Management Working Paper 70-64, 1964.

Stedry, A.C. Budgeting control: a behavioral approach. M.I.T., Sloan School of Management Working Paper No. 43-64, 1964 (a).

Stedry, A.C. Budgeting and employee behavior: a reply. J. Business, 37 , 1964 (b), 195-202.

Stedry, A.C. Aspiration levels, attitudes, and performance in a goaloriented situation. Industrial Management Review, 1962, 3, 60-76. 

Stedry, A.C. \& Charnes A. Some models of organization response to budgeted multiple goals. M.I.T., Sloan School of Management Research Paper No. 01-62, September 1962.

Stedry, A.C. \& Charnes A. Further exploration in the theory of multiple budgeted goals. M.I.T., Sloan School of Management Working Paper No. 12-63, February 1963. 



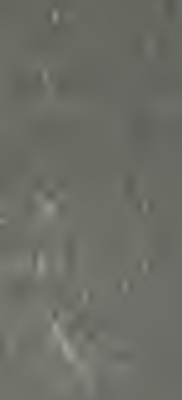





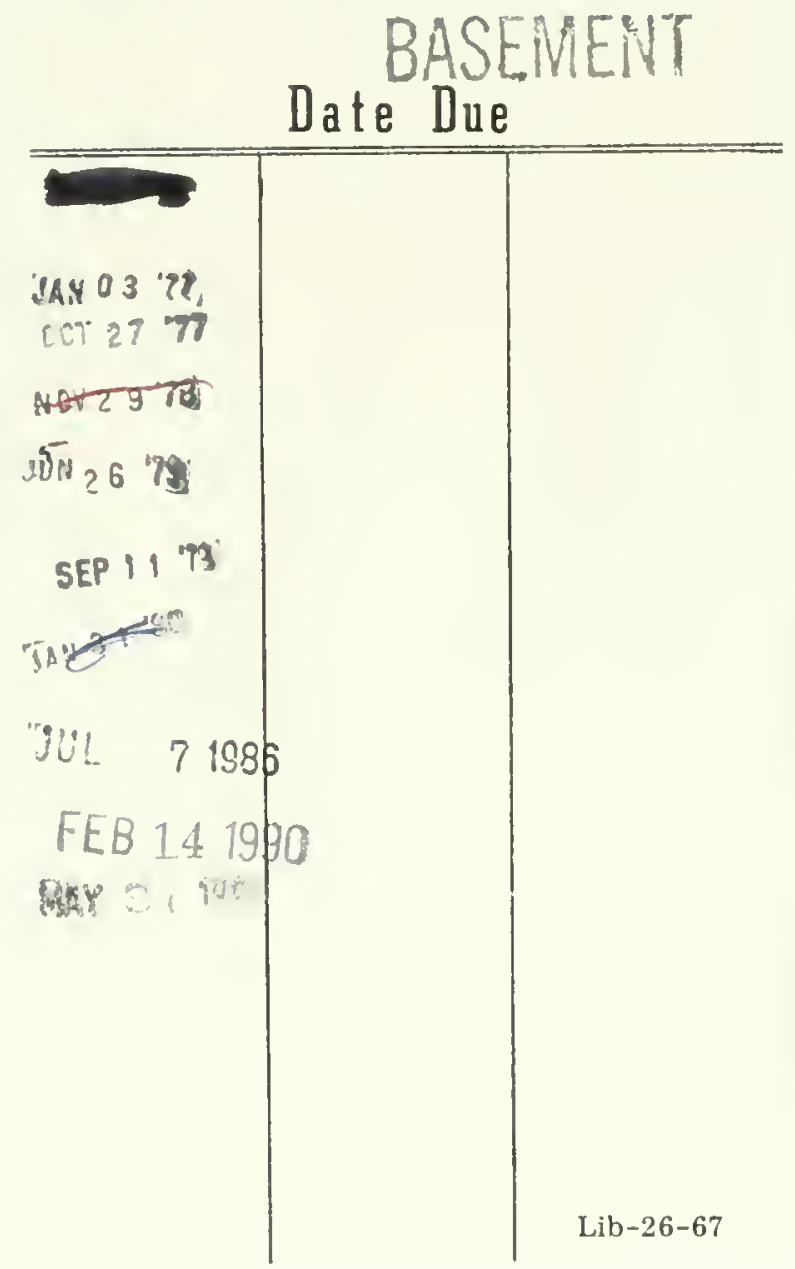




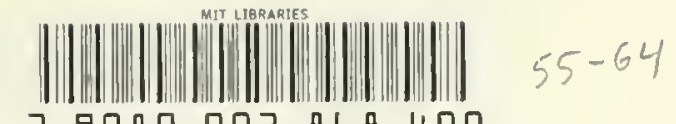

39080003868400
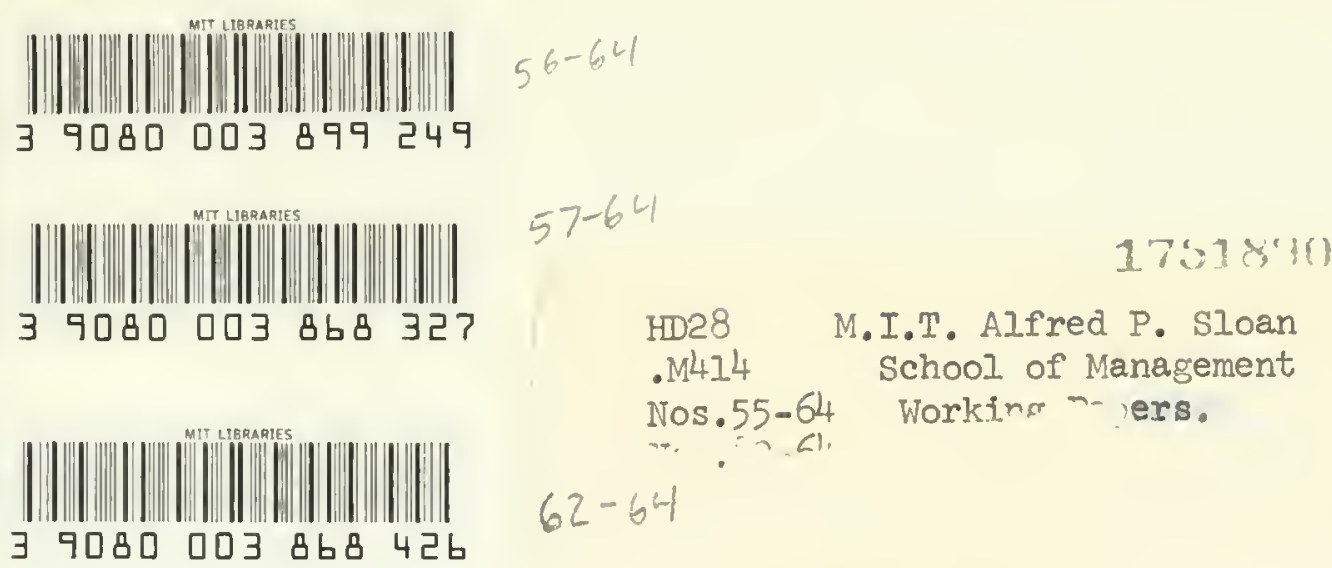

J 900 प0J Bb8
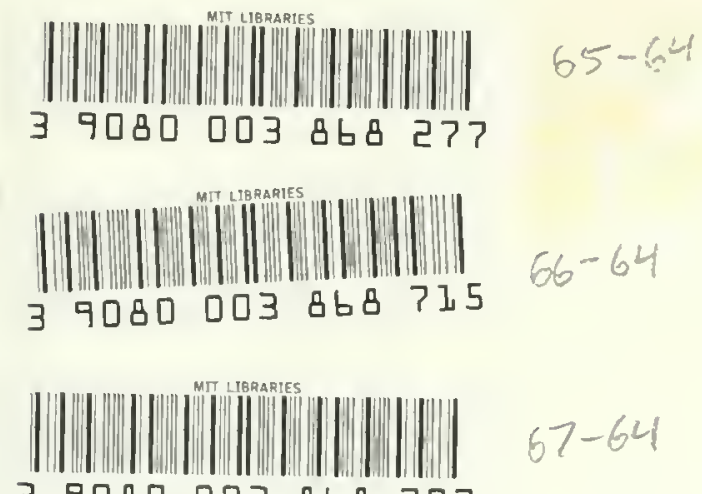

39080003868707
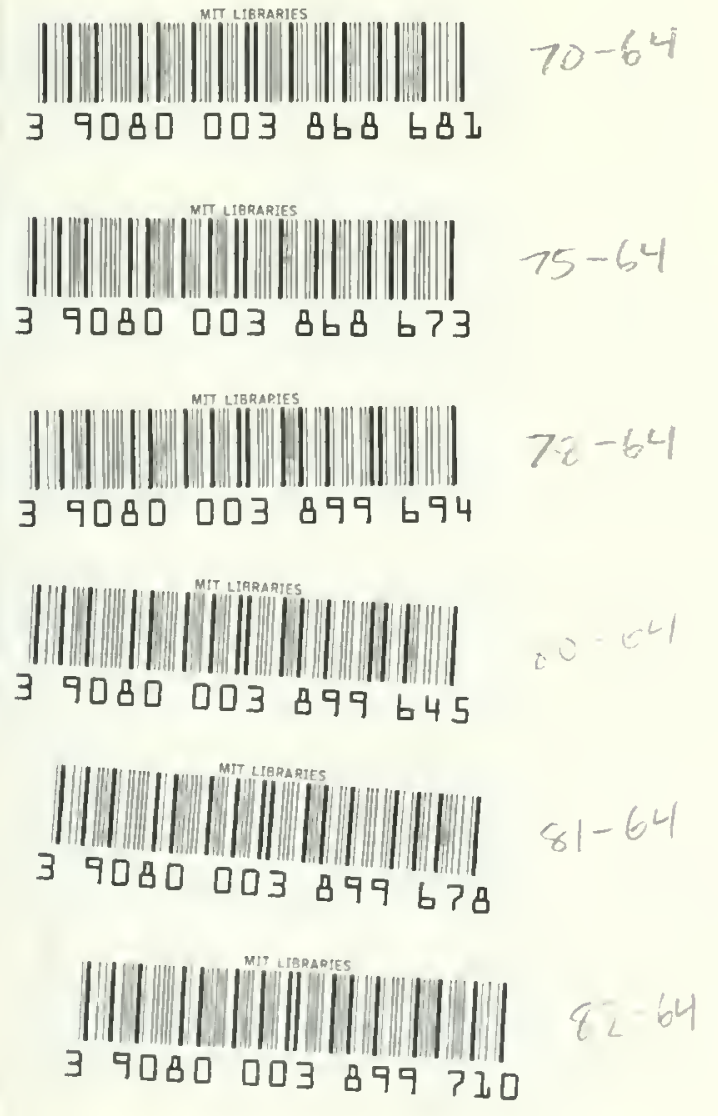
